\title{
Promoting the Co-Creation of Knowledge under Physical Distancing Conditions through the Participation of Youth in the Bunaken-Tangkoko-Minahasa Biosphere Reserve (North Sulawesi, Indonesia) ${ }^{\dagger}$
}

\author{
Alberto Hernández-Salinas 1,2, , María Viota 1, Miren Onaindia 1,3, Ibone Ametzaga-Arregi 1,3, Lorena Peña 1,3, \\ Beatriz Fernández ${ }^{1,3}$, Jasone Unzueta ${ }^{1}$, Yohannes Purwanto ${ }^{4}$, Johnny S. Tasirin ${ }^{5}$, N. Gustaf F. Mamangkey ${ }^{5}$ \\ and Fabiola B. Saroinsong 5
}

Citation: Hernández-Salinas, A.;

Viota, M.; Onaindia, M.;

Ametzaga-Arregi, I.; Peña, L.;

Fernández, B.; Unzueta, J.;

Purwanto, Y.; Tasirin, J.S.;

Mamangkey, N.G.F.; et al.

Promoting the Co-Creation of

Knowledge under Physical

Distancing Conditions through the

Participation of Youth in the

Bunaken-Tangkoko-Minahasa

Biosphere Reserve (North Sulawesi,

Indonesia). Environ. Sci. Proc. 2021, 5,

21. https://doi.org/10.3390/IECG

2020-08740

Published: 1 December 2020

Publisher's Note: MDPI stays neutral with regard to jurisdictional claims in published maps and institutional affiliations.

\section{Copyright: (c) 2020 by the authors.}

Licensee MDPI, Basel, Switzerland.

This article is an open access article distributed under the terms and conditions of the Creative Commons Attribution (CC BY) license (http://creativecommons.org/licenses/by/4.0/).

\author{
UNESCO Chair on Sustainable Development and Environmental Education, University of the Basque \\ Country (UPV/EHU), 48940 Leioa, Basque Country, Spain; viota.maria@gmail.com (M.V.); \\ miren.onaindia@ehu.es (M.O.); ibone.ametzaga@ehu.eus (I.A.-A.); lorena.pena@ehu.eus (L.P.); \\ beatriz.fernandezd@ehu.es (B.F.); mariaascension.unzueta@ehu.es (J.U.) \\ 2 IHEAL-CREDA, Université Sorbonne Nouvelle-Paris 3, 93322 Aubervilliers, France \\ 3 Department of Plant Biology and Ecology, University of the Basque Country (UPV/EHU), \\ 48940 Leioa, Basque Country, Spain \\ 4 Indonesian MAB National Committee and Research Center for Biology, The Indonesian Institute of Sciences \\ (LIPI), 16122 Bogor, Indonesia; purwanto.lipi@gmail.com \\ 5 Sam Ratulangi University (UNSRAT), 95115 Manado, Indonesia; jtasirin@unsrat.ac.id (J.S.T.); \\ gustaf@unsrat.ac.id (N.G.F.M.); fabiolasaroinsong@unsrat.ac.id (F.B.S.) \\ * Correspondence: albertohsirun@gmail.com; Tel.: +34-692718751 \\ + Presented at the 3rd International Electronic Conference on Geosciences, 7-13 December 2020; \\ Available online: https://iecg2020.sciforum.net/.
}

\begin{abstract}
Biosphere Reserves are laboratories of sustainability that provide local solutions to global challenges. They promote research, education and the creation of communities of practice that jointly generate knowledge that may be applicable in decision-making. The context of the global COVID-19 pandemic posed a great challenge to all teaching and learning processes and so to the co-creation of knowledge. In response, we developed an online teaching environment (webinar) to enhance the value of ecosystems and analyze the perception of youth, a key interest group in participatory governance of the territory, in relation to the provision of ecosystem services in the Biosphere Reserve in Indonesia. We took the experience of the Project "Ecosystem Services Assessment of the Basque Country" as a reference and developed a questionnaire on the perception of the provision of local ecosystem services. Our results contribute to establishing a baseline to understand the relationship of youth with the territory and to setting up an international scientific cooperation. This experience showed that the promotion of online solutions can help counteract the negative effects of the global pandemic on teaching and learning processes and also empower local actors in sharing local management in the territory.
\end{abstract}

Keywords: community of practice; webinar; scientific cooperation; biosphere reserve; ecosystem services

\section{Introduction}

In this hyperconnected global era, new technologies are showing the interconnectivities at all levels (the effects of local activities to global level as well as between the different socio-ecosystems) and are offering novel tools for addressing new challenges. The 
2030 Agenda for Sustainable Development encompasses these new challenges. The Sustainable Development Goals (SDG) represent a comprehensive framework that seeks to "leave no one behind" through working with and for all people. One of the recommendations identified is "implementing mechanisms that empower and actively encourage the participation of all in relevant decision-making processes, including in environmental matters, and ensure the respect, protection and fulfilment of human rights" [1]. The complexity of its practical implementation is often insufficiently acknowledged.

A disease like the COVID-19 pandemic currently has proved the human dependence on nature and ecosystems unbalanced equilibrium [2,3] and it has affected multiple dimensions of human well-being. For instance, global financial shocks increase fuel and food prices that even compromise other sectors such as major income related to tourism in deprived areas and education of quality. The COVID-19 pandemic has had negative consequences on all programmes and activities. This situation shows the interconnection among all life on this planet and the development of alternative teaching environments counteracting the physical distancing conditions is essential. Despite the fact that nature can be seen as a pathogenic reservoir, we are trying to demonstrate the positive contribution of nature to human well-being (e.g., Ecosystem services). The development of online teaching opportunities is essential to connect local communities to these global effects.

In addition, the preservation of biodiversity underpins the enhancement of resilient communities and safeguards the prosperity of humanity. For instance, the loss of biodiversity reduces ecosystems' healthy flows and increases the vulnerability to threats including negative impacts of climate change and thus undermines the ecosystem services that promote the sustainability of life and human well-being. [4,5].

Sustainable development is a complex notion and polysemic because it encompasses different elements. The Brundtland definition thus evokes the need to find balances to ensure: "compromise between the interests of present and future generations; compromise between the priorities of industrialized countries and those of developing countries; compromise between quality of life and preservation of ecosystems" [6] as well as among different social and economic groups in the same community. It is also giving room for different interpretations that each group of actors can follow.

The MAB Programme started in 1971 at UNESCO as "a long-term intergovernmental" and interdisciplinary programme on the Man and the Biosphere (MAB) [7]. In fact, the effort of the MAB Programme is focused on Biosphere Reserves as "Science for Sustainability support sites" - special places for testing interdisciplinary approaches to understand and manage changes and interactions between social and ecological systems, including conflict prevention and management of biodiversity [8].

Biosphere Reserves are places that provide local solutions to global challenges by fostering conservation outside "traditional protected areas" and are sustainably used. In addition, the programme develops activities to share experiences between sites and to promote research, environmental education, or training activities, within the World Network of Biosphere Reserves, to support cooperative decision through the participation of local communities and interest groups in landscape planning. Each site sets up an appropriate zoning system (core, buffer, and transition zones) to reach three functions: conservation, sustainable development, and logistic support. The logistic support function includes demonstration projects, environmental education and training, research, and monitoring related to local, regional, national, and global issues of conservation and sustainable development [9].

The World Network of Biosphere Reserve now is composed of 714 biosphere reserves in 129 countries. The decision body of the MAB programme (International Co-ordinating Council of Man and the Biosphere Programme (MAB-ICC)) recognized 25 new sites during its online meeting held from 27 to 28 October 2020 [10], in: Andorra, Benin, Cabo Verde, Comoros, Greece, India, Indonesia, Kazakhstan, Luxembourg, Maldives, Mongolia, Nigeria, Peru, Portugal, Russian Federation, Rwanda, Trinidad and Tobago. Indonesia 
received the recognition of three new biosphere reserves, one of them Bunaken-Tangkogo-Minahasa Biosphere Reserve, located in the North Sulawesi Province.

This new site is contributing to the conservation of different landscapes, ecosystems, species, and genetic variation. It is part of the hotspot of biodiversity Wallacean with a high level of endemism. The Biosphere Reserve zoning system is articulated around five different protected areas as core zones, from marine and coastal up to mountain and forest ecosystems [11]. This Indonesian Biosphere Reserve has a superficies of 746,412.54 ha. This superficies is similar to the Basque Country part with a superficies of 723,400 ha that includes as well, the Urdaibai Biosphere Reserve (Bizkaia).

This scientific cooperation between these two areas is included in the UNESCO World Network of Biosphere Reserves, with the general objective to promote the creation of a community of practice that jointly generates knowledge with the goal to guide decision-making processes for the Biospheres Reserves. The UNESCO Chair on Sustainable Development and Environmental Education of the University of the Basque Country (UPV/EHU) developed it in the Basque Country region [12].

The research project "Ecosystem Services Assessment of the Basque Country" developed in the Basque Country (Spain) the conceptual and methodological framework of the International Scientific Programme Millenium Ecosystem Assessment. The generated scientific knowledge highlighted the consequences of the changes in ecosystems and their services and it aims to be a tool for the identification of priority actions designed to avoid or minimize these human impacts. Moreover, it enhances its application in the public and private sectors by means of a community of practice [11]. The experience of the Project "Ecosystem Services Assessment of the Basque Country" of the UNESCO Chair from $\mathrm{UPV} / \mathrm{EHU}$ was taken as a reference, in which a transdisciplinary community of practice was promoted to apply the approach of ecosystem services in spatial planning [12].

The "community of practice" is defined as a group of people with a common interest, with the aim to co-generate and to co-manage knowledge and integrate it among all stakeholders. Special attention must be drawn to the importance of establishing a constructive and mutually comprehensible dialogue between all of them. The transdisciplinary community of practice involved politicians, technical experts, and scientists [12].

It can be replicated as:

- a tool for the identification of priorities and actions to avoid or minimize human impacts on ecosystems and their services;

- a tool for highlighting the policies and actions that impact positively on the conservation of natural capital;

- $\quad$ a tool for the promotion of participatory approach with university support.

The present experience in Indonesia is aimed at providing tools to analyze the perception of youth in relation to the provision of ecosystem services in the new Biosphere Reserve in Indonesia. It also pursues the goal of allowing them to become local actors of changes in this global world and to include them in the governance of their territory. This work applied the co-creation of knowledge and the setup of a community of practice approach to promote inclusive participatory management of their territory. It is based on previous experience of the Project "Ecosystem Services Assessment of the Basque Country" from the UNESCO Chair on Sustainable Development and Environmental Education of the University of the Basque Country (UPV/EHU).

\section{Methods}

The experience in Indonesia was developed within the framework of an online training untitled "E-Life Long Learning Project", funded by UNESCO. It was conceived to foster new forums to promote local leadership through the incorporation of youth vision in the future decision-making structure of the Biosphere Reserve. In this sense, this "E-Life 
Long Learning" webinar and subsequent similar activities, integrated policy makers, research and civic society presentations to share their vision. It has also spread activities through publications, seminars, and audiovisual materials.

As sustainable development should be guided by scientific knowledge, social agreements and political decisions, there is need for the co-creation of knowledge. In addition, in collaboration with the University Sam Ratulangi (Manado, Indonesia) and the Indonesian MAB National Committee, The Indonesian Institute of Sciences (LIPI), a scientific basis was provided to interpretate the vision of the ecosystem-based approach and strengthen the relationship between people and nature.

The information was collected mainly through the E-Lifelong Learning for Youth webinar, held on 12 August 2020. Two sources of information were analyzed, to understand the vision of youth from the Biosphere Reserve:

- The pre-questionnaires of the participants to the Webinar. This questionnaire was necessary to have been completed before receiving the code access for the seminar;

- A questionnaire that was presented during the seminar about the perception of the ecosystem services' contribution in relation to each socio-ecosystem ("environmental unit") within the Bunaken-Tangkoko-Minahasa Biosphere Reserve.

A total of 75 people completed the pre-questionnaire. It was composed of 29 questions to characterize the sample population, their relationship with nature, their vision and their level of environmental activism as well as information on how they knew about the E-Lifelong Learning webinar.

A second questionnaire was developed on the perception of the provision of ecosystem services on a semi-quantitative scale (minimum 0, maximum 5). It was structured around three blocks of services (provision, regulation, cultural [11]), disaggregated by 20 services and in relation to 12 environmental units present in the Bunaken-Tangkoko-Minahasa Biosphere Reserve.

A total of 74 perception questionnaires ( $n=17,760$ records) were collected from students of two faculties of UNSRAT (Faculty of Agriculture and Faculty of Fisheries and Marine Science) and analyzed using general linear models [11].

\section{Results and Discussion}

The partial analysis of the pre-questionnaire aims to understand the perception of the respondents, in particular their favorite places (maximum three choices). A great majority $(80 \%)$ chose mountain/forest and coastal area as their favorite places. Places associated with water such as waterfalls were also important places frequently mentioned. A total of 178 different locations were taken into account (Figure 1).

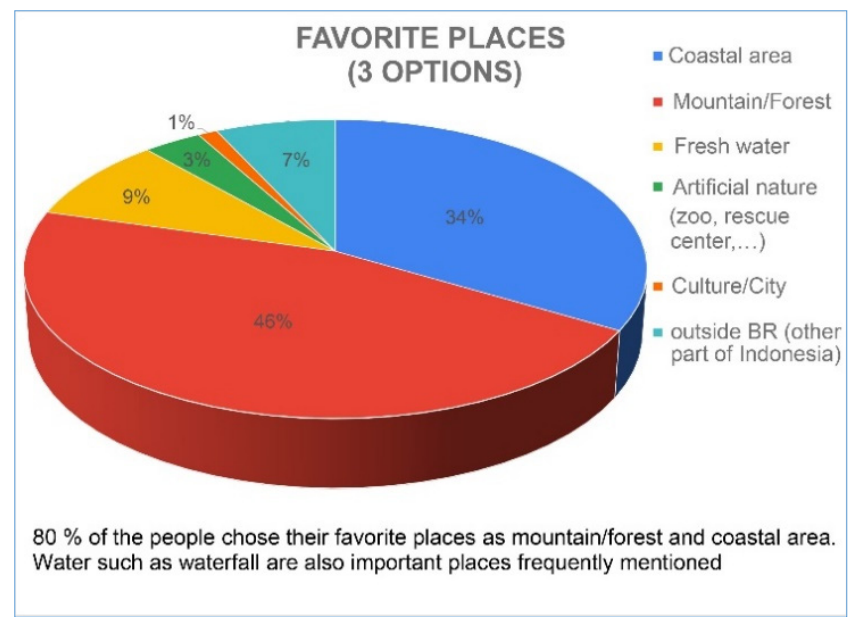

Figure 1. Respondents favorite places in the Bunaken-Tangkoko-Minahasa Biosphere Reserve. 
Two types of information were provided. The first one concerned generic locations or types of places such as beaches, mountains, waterfalls, etc. The second one dealt with specific places (e.g., Klabat mountain, Bunaken National Park or a specific island of the park, etc.). The specific place has 119 sites, 12 outside the Biosphere Reserve (68\% of the places are specific location). The 107 specific locations are represented in the map below (Figure 2).

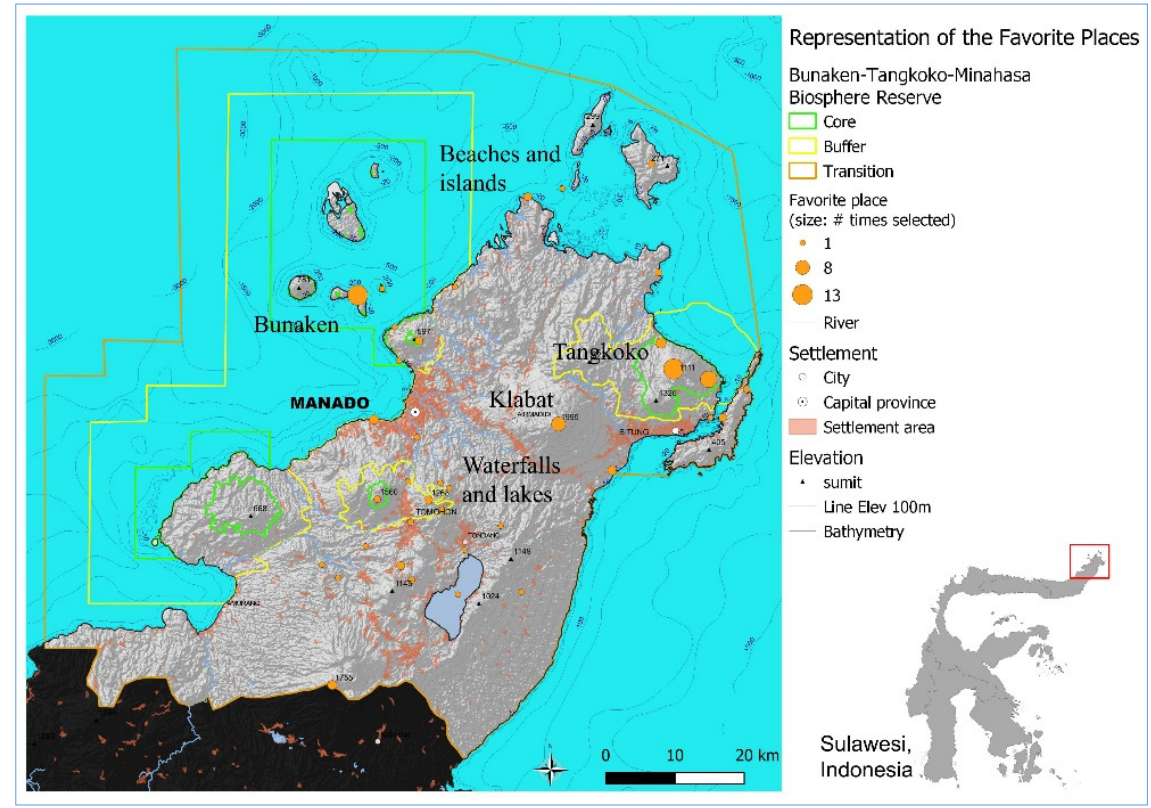

Figure 2. Favorite places and the zoning system of the Bunaken-Tangkoko-Minahasa Biosphere Reserve (BR) (limit of the BR, extracted from nomination dossier-created by the authors).

Two areas are the most representative: Bunaken Marine National Park and Tangkoko Conservation Forest Management Unit (KPHK). KPHK is composed of three protected areas: Dua Saudara volcano Nature Reserve, and two Nature recreation Park (Batu Putih and Batu Angus). The mountain Klabat is also frequently mentioned. It is the higher peak in the area $(1995 \mathrm{~m})$. The Tomohon area has a large number of waterfalls, lakes (e.g., Linow or Tondano) and hills. It also represents an attractive area mentioned by the participants. Some specific beaches and islands (e.g., Bangka, Lembeh) were also mentioned.

The second analysis concerns the perception of the contribution of the ecosystem services by each environmental unit and its differences between the two UNSRAT faculties. The results of this evaluation of the questionnaires are shown in Table 1.

The block of ecosystem services that received the highest average evaluation was the one corresponding to the "cultural services" group (average scored 3.06), in particular the "scientific knowledge" service. The most valued environmental unit corresponds to "primary and secondary forest" (average scored 3.94). The disaggregation by each services group shows that "food supply", "regulation of air quality", and "scientific knowledge" were the most valued respectively within provision, regulation, and cultural services groups (Table 1).

On the other hand, there are significant differences $(p<0.05)$ between students perception of both faculties. Both the faculties agreed on the importance of "food" as well as "scientific knowledge". However, in the regulating services group, "water regulation" was the most important for the Faculty of Agriculture students and "regulation of air quality" for the Faculty of Fisheries and Marine Sciences. Concerning the environmental unit, forest ecosystem was rated as very important in both faculties. However, The Faculty of Fisheries and Marine Sciences also scored coastal and sea with a high value (median and mode). 
Table 1. Descriptive statistics of the evaluations obtained in the questionnaire using $\mathrm{R}$ statistic programme [13] ( $n=17,760$ records: 35 questionnaires from Agriculture Faculty and 39 questionnaires from Fishery and Marine Sciences Faculty). ${ }^{*}$ Global: total of respondents for both faculties.

\begin{tabular}{|c|c|c|c|c|c|}
\hline Group/Faculty & ITEM & Mean & Median & Mode & SD \\
\hline \multicolumn{6}{|c|}{$\begin{array}{c}\text { ECOSYSTEM SER- } \\
\text { VICE }\end{array}$} \\
\hline & PROVISIONING & 2.93 & 3 & 3 & 1.58 \\
\hline Global * & food & 3.17 & 4 & 5 & 1.70 \\
\hline Fish \& Marine Sc. & food & 3.15 & 4 & 5 & 1.84 \\
\hline \multirow[t]{2}{*}{ Agriculture } & food & 3.20 & 3 & 3 & 1.53 \\
\hline & REGULATING & 2.93 & 3 & 3 & 1.49 \\
\hline Global * & $\begin{array}{l}\text { regulation of air } \\
\text { quality }\end{array}$ & 3.24 & 3 & 3 & 1.32 \\
\hline Global * & water regulation & 3.22 & 3 & 4 & 1.45 \\
\hline Global * & $\begin{array}{l}\text { maintenance of soil } \\
\text { fertility }\end{array}$ & 3.20 & 3 & 4 & 1.44 \\
\hline Fish \& Marine Sc. & $\begin{array}{c}\text { regulation of air } \\
\text { quality }\end{array}$ & 3.34 & 3 & 3 & 1.36 \\
\hline \multirow[t]{2}{*}{ Agriculture } & water regulation & 3.30 & 3 & 4 & 1.37 \\
\hline & CULTURAL & 3.06 & 3 & 4 & 1.44 \\
\hline Global * & scientific knowledge & 3.32 & 3.5 & 4 & 1.33 \\
\hline Global * & $\begin{array}{l}\text { environmental edu- } \\
\text { cation }\end{array}$ & 3.25 & 4 & 4 & 1.40 \\
\hline \multirow{3}{*}{$\begin{array}{c}\text { Fish \& Marine Sc. } \\
\text { Agriculture }\end{array}$} & scientific knowledge & 3.22 & 3 & 4 & 1.38 \\
\hline & scientific knowledge & 3.42 & 4 & 4 & 1.27 \\
\hline & $\begin{array}{l}\text { ENVIRONMEN- } \\
\text { TAL UNIT }\end{array}$ & & & & \\
\hline Global * & Pri. \& Sec. Forest & 3.94 & 4 & 5 & 1.16 \\
\hline Global* & Plantation \& Garden & 3.44 & 4 & 4 & 1.24 \\
\hline Global * & Coastal \& Sea & 3.40 & 4 & 5 & 1.43 \\
\hline Fish \& Marine Sc. & Pri. \& Sec. Forest & 3.86 & 4 & 5 & 1.26 \\
\hline Fish \& Marine Sc. & Coastal \& Sea & 3.65 & 4 & 5 & 1.33 \\
\hline Agriculture & Pri. \& Sec. Forest & 4.03 & 4 & 5 & 1.02 \\
\hline
\end{tabular}

The results obtained highlighted the importance of primary and secondary forest and they are in line with the Bunaken-Tangkoko-Minahasa Biosphere Reserve design. It underscores youth's perception of the multifunctionality of forest ecosystems, which provide multiple benefits for the entire territory, with emphasis on the generation of knowledge and in supplying food as well as hydrological and air regulation processes that can be addressed through a water cycle approach.

The results obtained are consistent with the nomination process of the BunakenTangkoko-Minahasa Biosphere Reserve, which is based on the premise of providing innovative mechanisms that promote the generation of scientific knowledge that contributes to local and global sustainable development and its input to the World Network of Biosphere Reserves. Of note also, were the interrelationships between all ecosystems and the pertinence of this integral Biosphere Reserve landscape spatial unit.

Our results contribute in establishing a baseline to understand the relationship of youth with the territory within the framework of the MAB Programme and to set up an international scientific cooperation. In addition, the ecosystem services approach highlights the role of the water cycle as a connector to facilitate climate change adaptation in the new Biosphere Reserve. 
This opportunity for in situ research and testing of sustainable solutions revolves around primary and secondary forest. It may guide future lines of work aimed to reinforce the knowledge about the interrelationships of these ecosystems with other environmental units of the territory. It also may promote the enhancement of synergies between the real uses of the territory and the socioecological demand and its perception, and support novel mechanisms to promote the co-creation of scientific knowledge that contribute to the development of local communities.

It should be noted that these general results were collected through questionnaires distributed during the E-Lifelong Learning online training to participants who had an interest in the environment and among students of the UNSRAT Faculties. Their experience and educational orientation may have also reinforced these conclusions. We can also conclude that inside of the same group ("students") there were also some variations which confirms the challenge to develop transdisciplinary research methods.

This type of work, which focuses on young people, highlights the key present and future role of youth in global sustainability processes, as well as in shared local management of this site, facilitated by UNESCO mandates to dynamize spaces in which their vision and participation are promoted.

For all these reasons, an experience such as the one carried out, driven from the transfer of knowledge and supported by a joint co-creation, promotes a multidisciplinary community of practice that supports the relevant role of youth. It can be a very valuable tool for generating synergies and supporting joint management of spaces in promoting harmonious conservation and increasing the resilience of local communities, including nature, health, economy, and culture. These contributions can be extrapolated at global agendas.

\section{Conclusions}

Our results validate the logistic support function of the Bunaken-Tangkoko-Minahasa Biosphere Reserve as a generating space for scientific knowledge that allows the understanding and enhancing of the vision of youth. The results regarding the perception of ecosystem services encourage the development of an integral landscape vision to embrace different ecosystems, the possibility to combine scientific approach (marine and terrestrial). The Biosphere Reserve is presented as a favorable space in which to combine biophysical and social information. Furthermore, this experience encourages the creation of a community of practice in which youth plays a prominent role in facilitating leadership.

It is important to highlight the role of scientists in the management structure as facilitator of solving problems, identifying potential conflict based on perception analysis, as well as supporting international cooperation and sharing experiences. By including people's perception in the analysis, the sense of belonging is reinforced together with the sentiment to contribute to other scales (other Biosphere Reserves, international agendas, etc.).

Supplementary Materials: The datasets generated during the study are available online at https://www.mdpi.com/2673-4931/5/1/21/s1, poster presentation.

Author Contributions: A.H.-S. and M.V. conceived the idea and analyzed the data; Y.P., J.S.T., N.G.F.M. and F.B.S. performed the organization of the webinar and collected information; M.O., I.A.A., L.P., B.F. and J.U. provided methodology, guidance, and university cooperation. All authors have read and agreed to the published version of the manuscript.

Institutional Review Board Statement: The study was conducted in coordination and according to the guidelines and approved methodology of the previous activities implemented in the Basque Country region by the UNESCO Chair on Sustainable Development and Environmental Education, University of the Basque Country (UPV/EHU).

Informed Consent Statement: Not applicable. 
Data Availability Statement: The datasets generated during the study are available in the Supplementary materials link.

Acknowledgments: The authors would first like to thank the UNESCO Jakarta Regional Office, that supports Open Sciences, for their financial support to organize the webinar: "E-Life Long Learning on Biosphere Reserve for Youth" and the webinar on Eco-Hydrology, and for their participation. It has played an important part in disseminating the contributions of this article as well as guidance in the development of these seminars. On the other hand, they would also like to thank the Sam Ratulangi University, for its technical contribution and logistical support in motivating young people during the restrictions period of COVID-19 pandemic and to solve all administrative issues. In turn, we also thank the organizations involved in the management body of the Bunaken-Tangkoko-Minahsa Biosphere Reserve, in Indonesia: BTN Bunaken, BKSDA and BAPPEDA, as well as the NGOs and youth groups (i.e., Sukma Riverningtyas), the Indonesian MAB National Committee, LIPI and by extension to the seminar participants. We hope that these initiatives will support the foundations for a future Community of Practice in this region. Finally, this exchange work between universities is also promoted by the UNESCO Chair on Sustainable Development and Environmental Education of the UPV/EHU. This UNESCO Chair is promoting a Community of Practice in the Basque Country with the support of the local Basque Government, the Provincial Council of Bizkaia and all the local actors in this territory that are participating.

Conflicts of Interest: The founding sponsors, UNESCO Jakarta, had no role in the design of the study; in the collection, analyses, or interpretation of data; in the writing of the manuscript, and in the decision to publish the results.

\section{References}

1. UNCDP. Leaving No One Behind. United Nations Committee for Development Policy UNCDP-ECOSOC, 2018. Excerpt from Committee for Development Policy, Report on the twentieth, 2018, Supplement No. 13 (E/2018/33). Available online: https://sustainabledevelopment.un.org/content/documents/2754713_July_PM_2._Leaving_no_one_behind_Summary_from_UN_Committee_for_Development_Policy.pdf (accessed on 19 November 2020).

2. Gibb, R.; Redding, D.W.; Chin, K.Q.; Donnelly, C.A.; Blackburn, T.M.; Newbold, T.; Jones, K.E. Zoonotic host diversity increases in human-dominated ecosystems. Nature 2020, 584, 398-402.

3. Serra-Cobo, J.; López-Roig, M. Bats and Emerging Infections: An Ecological and Virological Puzzle. In Advances in Experimental Medicine and Biology Book Series; Springer International Publishing: Cham, Switzerland, 2016; Volume 972, pp. 35-48.

4. UN Environment. Global Environment Outlook-GEO-6: Healthy Planet, Healthy People; UN Environment: Nairobi, Kenya, 2019. doi:10.1017/9781108627146.

5. MEA-Millenium Ecosystem Assessment. Ecosystem and Human Well-Being: Synthesis; Millenium Ecosystem Assessment: Washington, DC, USA, 2005.

6. Mancebo, F. Le développement durable en question(s). Cybergeo Eur. J. Geogr. 2007. Epistémologie, Histoire de la Géographie, Didactique, mis en Ligne le 09 Octobre 2007. Available online: https://journals.openedition.org/cybergeo/10913 (accessed on 19 November 2020).

7. UNESCO. Résolution. In Proceedings of the Acte de la Conférence Générale, Paris, France, 12 October-14 November 1970.

8. UNESCO. World Network of Biosphere Reserves: Learning Sites for Sustainable Development. 2019-2020; UNESCO: Paris, France, 2020.

9. UNESCO. Réserves de Biosphère: la Stratégie de Séville et le Cadre Statutaire du Réseau Mondial; UNESCO: Paris, France, 1996.

10. UNESCO. Tenty-Five-Sites-Join-Unescos-World-Network-Biosphere-Reserves. $2020 . \quad$ Available online: https://en.unesco.org/news/twenty-five-sites-join-unescos-world-network-biosphere-reserves (accessed on 19 November 2020).

11. The Indonesian MAB National Committee, LIPI. Nomination of Bunaken Tangkoko Minahasa Biosphere Reserve; No. Arsip: LIPI2020 0116; The Indonesian MAB National Committee: Bogor, Indonesia, 2019.

12. Peña, L.; Fernández de Manuel, B.; Méndez-Fernández, L.; Viota, M.; Ametzaga-Arregi, I.; Onaindia, M. Co-Creation of knowledge for Ecosystem Services Approach to Spatial Planning in the Basque Country. Sustainability 2020, 12, 5287, doi:10.3390/su12135287.

13. R Core Team. R: A Language and Environment for Statistical Computing; R Core Team: Vienna, Austria, 2016. 